\title{
Determination of the radiation dose due to radon ingestion and inhalation
}

\author{
P. Ravikumar • R. K. Somashekar
}

Received: 13 July 2012/Revised: 13 February 2013/Accepted: 3 March 2013/Published online: 26 April 2013

(C) Islamic Azad University (IAU) 2013

\begin{abstract}
The distribution of radon in ground and surface water samples in Sankey Tank and Mallathahalli Lake areas was determined using Durridge RAD-7 analyzer with RAD $\mathrm{H}_{2} \mathrm{O}$ accessory. The radiation dose received by an individual falling under different age groups (viz., 3 months; 1, 5, 10, 15 years and adult) depending upon their average annual water consumption rate was attempted. The mean radon activity in surface water of Sankey Tank and Mallathahalli Lake was $7.24 \pm 1.48$ and $11.43 \pm 1.11 \mathrm{~Bq} / \mathrm{L}$, respectively. The average radon activities ranged from $11.6 \pm 1.7$ to $381.2 \pm 2.0 \mathrm{~Bq} / \mathrm{L}$ and $1.50 \pm 0.83$ to $18.9 \pm 1.59 \mathrm{~Bq} / \mathrm{L}$, respectively, in 12 groundwater samples each around Sankey Tank and Mallathahalli Lake areas. Majority of the measured groundwater samples (viz., $100 \%$ in Sankey Tank area and $75 \%$ in Mallathahalli Lake area) showed mean radon values above the EPA's maximum contaminant level of $11.1 \mathrm{~Bq} / \mathrm{L}$ and only $66.67 \%$ of samples in Sankey Tank area showed radon above the WHO and EU's reference level of $100 \mathrm{~Bq} /$ $\mathrm{L}$. The overall radiation dose due to radon emanating from water in the study area was increasing with increase in age and water consumption rates, but significantly lower than UNSCEAR and WHO recommended limit of $1 \mathrm{mSv} / \mathrm{year}$ except for few groundwater samples in Sankey Tank area (i.e., $0.92,0.99$ and $1.39 \mathrm{mSv} / \mathrm{year}$ ). The radiation dose rate received by bronchial epithelium via inhalation was very high compared to that by stomach walls via ingestion.
\end{abstract}

Keywords Aerator - Closed loop - Decay correction . Humidity $\cdot$ Desiccant $\cdot$ Polonium $\cdot$ Radioactivity

P. Ravikumar $(\bowtie) \cdot$ R. K. Somashekar

Department of Environmental Science,

Bangalore University, Bangalore 560056, India

e-mail: prakruthiravi@gmail.com

\section{Introduction}

Water quality is one of the most important parameters of environmental studies and it is vital to have regulations about natural radioactivity in drinking water, though water pollution as a risk factor for cancer appears small. The occurrence of radionuclides in drinking water gives rise to internal exposure, directly via their decay processes, when directly taken into the body through ingestion and inhalation and indirectly, when they are incorporated as part of the food chain (Duenas et al. 1999). Hence, the measurement of radioactivity in drinking water permits one to determine the extent of exposure of the population to radiation from the habitual consumption of water.

Radon $\left({ }^{222} \mathrm{Rn}\right)$, being naturally occurring radioactive, noble gas with a half-life of 3.82 days, is one such important potential health hazard concerning radiation hygiene in modern days. It originates from the radioactive decay of naturally occurring uranium (Somlai et al. 2007) and radium deposits, which is picked up by groundwater passing through rocks and soil containing such radioactive substances and then enters water supplies, when this water is pumped up a well (Gruber et al. 2009). Several studies on radon and its correlation with geology have been attempted in different parts of the world (Tanner 1986; Ramola et al. 1989; Choubey et al. 1994). Radon migrates through pores in soil, fractures in rocks and along other weak zones, such as shears, faults, thrust, etc., (Choubey et al. 1994, 2000; Ramola et al. 1988, 1990) and its migration in geological structure is governed by two mechanisms, namely diffusion and convection. All groundwater contains radon from both dissolved radium and from recoil of radon from soil and rocks, which can diffuse over large distances in water. Radon concentration though varies widely from place to place and its contents in 
ground waters sources have led to a great interest in hydrogeological and geological engineering. In situ field measurements of radon in natural water/soil are useful in (a) field measurements of uranium deposits, (b) search for hidden faults/thrusts, etc., (c) continuous monitoring of radioactivity of drinking, mining and thermal water for radiation protection purposes, and (d) search for seismic related changes in radon content of water and soil (Arora et al. 2011).

Public exposure to waterborne ${ }^{222} \mathrm{Rn}$ and its short-lived radioactive progenies/decay products (viz., such as ${ }^{218} \mathrm{Po}$, ${ }^{214} \mathrm{~Pb},{ }^{214} \mathrm{Bi}$ and ${ }^{214} \mathrm{Po}$ ) may occur by ingestion (drinking water containing ${ }^{222} \mathrm{Rn}$ ) and by inhalation (breathing ${ }^{222} \mathrm{Rn}$ gas in indoor/outdoor air which has been released from household water), both mechanisms posing a potential health risk (Yu et al. 1994; Barnett et al. 1995; Tayyeb et al. 1998; Somashekar and Ravikumar 2010; Arora et al. 2011). This occupies from the natural radiation sources more than half of the dose exposure $(\sim \geq 50 \%)$ reaching the public across the globe (ICRP 1994; UNSCEAR 2000; Somlai et al. 2007). A very high level of radon in drinking water can lead to a significant risk of developing internal organ cancers, primarily stomach and gastrointestinal cancer (Zhuo et al. 2001; Kendal and Smith 2002). Radon, when present at high concentration, is also known to cause lung cancer (Folger et al. 1994; Khan 2000), originally called the Schneeberger Lungen - krankheit or Schneeberg lung disease (Enderle and Friedrich 1995; Boice et al. 2003). The risk due to exposure of the ingested radon with intake of the water is smaller than the risk of developing lung cancer (Folger et al. 1994; Khan 2000) from inhaled radon released to air from exhalation from the same water. Because certain building materials with high concentrations of radium, domestic water with high concentrations of radon and their utilitarian purposes, and even the type of soil can make major contributions to indoor radon exposure (Kearfott 1989; Sohrabi 1998; Li et al. 2006). Based on a National Academy of Science report, Environmental Protection Agency (EPA 1991) estimated that radon in drinking water causes about 168 cancer deaths per year; $89 \%$ are lung cancer caused by breathing radon released from water to the indoor air, and only $11 \%$ account for stomach cancer caused by consuming water containing radon.

To protect the public from consequences of excessive exposure to radiation due to radon in their environment (Gillmore et al. 2002), mainly from the risk of lung cancer, it is necessary to understand the levels of radon in each source including household water, particularly water from groundwater sources. A number of investigators have reported much higher radon concentrations in public drinking water around the world (Savidou et al. 2001; Al-Kazwini and Hasan 2003; Xinwei 2006; Ali et al. 2010; Khan et al. 2010; Nikolov et al. 2011; Bourai et al. 2012; Muhammad et al. 2012; Bourai et al. 2012; Chandrashekara et al. 2012). However, only few researchers have attempted to study the variation in dose exposure rate among different age groups. To name a few, Jing Chen (2010) attempted a study on sensitivities and doses to children from intakes of various radionuclides (except radon) by ingestion relative to adults by considering six different age groups (viz., 0-1, $1-2,2-7,7-12,12-17$, and adult $>17$ years) and average annual consumption rates for Canadian populations. Muhammad et al. (2012) arrived at the age-dependent (viz., $0-1,2-16$, and $>16$ years age groups) associated committed effective doses due to the ingestion of ${ }^{222} \mathrm{Rn}$ as a consequence of direct consumption of drinking water. Hence, this research presents the variation in radon activity in 24 groundwater samples from bore wells, which are being used for domestic purposes and in surface water from Sankey Tank and Mallathahalli Lake located in the Bangalore North taluk, Bangalore Urban district. Further, dose assessments to International Commission on Radiological Protection (ICRP) proposed age groups (viz., 3 months, 1, $5,10,15$ years, and adult) and internal organs based on these radon data were attempted.

\section{Study area}

Bangalore district is situated in the heart of the South Deccan Plateau in peninsular India to the South-Eastern corner of Karnataka State between the latitudinal parallels of $12^{\circ} 39^{\prime} \mathrm{N}$ and $13^{\circ} 18^{\prime} \mathrm{N}$ and longitudinal meridians of $77^{\circ} 22^{\prime} \mathrm{E}$ and $77^{\circ} 52^{\prime} \mathrm{E}$, at an average elevation of about $920 \mathrm{~m}(3,020 \mathrm{ft})$ covering an areal extent of land of about 2,174 sq.km (Bangalore rural and urban districts). Bangalore district (Bangalore rural and urban districts) is bordered with Kolar and Chikkaballapur in the northeast, Tumkur in the northwest, Mandya and Ramanagaram in the southeast and Mysore and Tamil Nadu in the south. Bangalore urban district is bounded in all the directions by Bangalore rural district except in southeast, where the district is bounded by Dharmapuri district of Tamil Nadu state. Bangalore urban district is divided into three taluks namely Bangalore North, Bangalore South and Anekal (Fig. 1). Major part of the district (viz., Bangalore North and South taluks) is drained by Shimsha and Kanva rivers of Cauvery basin (Catchment area of 468 sq.km, which includes Nelamangala and Magadi taluks of Bangalore rural also). Anekal taluk is drained by South Pennar river of Ponnaiyar basin, which takes its birth from Nandi hills and flows towards the south (Catchment area is 2,005 sq.km which covers Devanahalli and Hoskote taluks of Bangalore rural district).

The Bangalore North taluk is more or less a level plateau and lies between 839 and $962 \mathrm{~m}$ above mean sea level. In the middle of the taluk, there is a prominent ridge running NNE-SSW. The highest point (Doddabettahalli $962 \mathrm{~m}$ ) is 


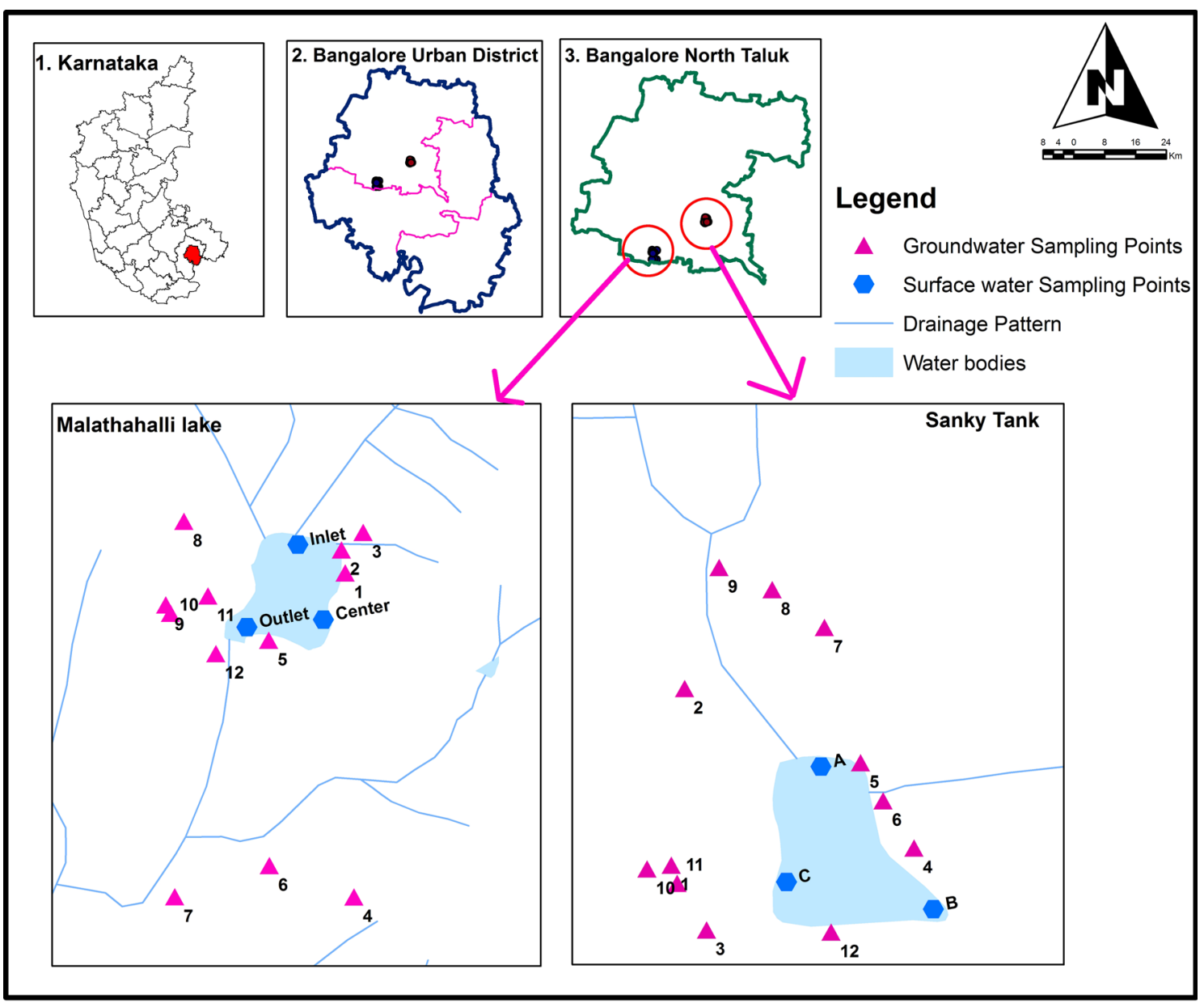

Fig. 1 Location map of the study area showing sampling points and drainage pattern

on this ridge. The gentle slopes and valleys on either side of this ridge hold better prospects of groundwater utilization. The low-lying area is marked by a series of tanks varying in size from a small pond to those of considerable extent, but all very shallow. Bangalore North supports about 98 tanks irrigating about 2,102 ha of land. These are mostly seasonal and carry water for about 6 months in a year. The biggest tank in the Taluk is Hesaraghatta with a catchment area of 490 sq.km. The total surface water potential created in the taluk is about 2,330 ha.

Bangalore is climatically a well-favored district having seasonally dry tropical Savanna climate with four seasons. The dry season with clear bright weather (DecemberFebruary), summer characterized by high temperatures (March-May), followed by the South-West monsoon season (June-September) and post-monsoon/retreating monsoon season (October-November). Typical monsoonal climate prevails in the district with major contribution of rainfall during southwest monsoon. Two rainy seasons come one after the other but with opposite wind regimes, corresponding to the South-West and North-East monsoons. Of the total rainfall, contribution from South-West monsoon is 54.18 and $26.53 \%$ is from North-East monsoon. In addition to this, Pre-monsoon showers contribute significant rainfall of $18.53 \%$. In general, pre-humid to semi-arid climatic conditions prevail in the district. The mean annual rainfall is $859.6 \mathrm{~mm}$, with three different rainy periods covering 8 months of the year. June to September being rainy season receives $54 \%$ of the total annual rainfall during South-West monsoon period and $241 \mathrm{~mm}$ during the Nort-East monsoons (October to November). Bangalore records agreeable range of temperatures, high temperatures during April with daily mean temperatures of $33.4^{\circ} \mathrm{C}$ and mean daily minimum in the month of December/January at $25.7^{\circ} \mathrm{C}$, as the coolest month. The mean monthly relative humidity is the lowest during the month of March at $44 \%$ and records highest between the months of June and October at 80-85 \%. The surface winds in Bangalore have seasonal character with the easterly components predominating during one period followed by the westerly in the other. The high wind speed averages $17 \mathrm{kmph}$ during the westerly winds in the month of July and a minimum of 8-9 kmph during the months of April and October. 
Physiographically, the district can be divided into rocky upland, plateau and flat topped hills at an general elevation of about $900 \mathrm{~m}$ amsl with its major part sloping towards south and southeast forming pediplains interspersed with hills all along the western part. The pediplains form the major part of the district underlain by granites and gneisses with the highest elevation of 850-950 m amsl. Major part of the pediplain constitutes low relief area having matured dissected rolling topography with erosional land slope covered by a layer of red loamy soil of varied thickness. Major part of the pediplains is dissected by streamlets flowing in southern direction. The soils of the districts can be broadly grouped into red loamy soil and lateritic soil. Red loamy soils generally occur on hilly to undulating land slope on granite and gneissic terrain, mainly seen in the eastern and southern parts of Bangalore North and South taluks. Laterite soils occur on undulating terrain forming plain to gently sloping topography of peninsular gneissic region, mainly covered in Anekal taluk and western parts of Bangalore North and South taluks.

Bangalore has no major rivers flowing in the district. The Arkavati River flows in the district for a small distance in Bangalore North taluk and the South/Dakshina Pinakini touches the borders of the district to the NorthEast of the Anekal taluk. The Vrishabhavati, a tributary of Arkavathi that takes its birth in the Bangalore City at Basavanagudi, flows in the district before joining the Arkavati near Muduvadidurga and the Suvarnamukhi from Anekal taluk joins the tributary before joining the Arkavati. The drainage pattern of the Bangalore North taluk is governed by the Granitic ridge running NNE-SSE almost to the middle of the taluk. The drainage towards the east is made up of a network of nalas, generally flowing from west to east with storage tanks along the nalas, ultimately feeding the South Pinakini River on the western half; the nalas generally flow from east to west, ultimately draining into the Arkavati River. Degree of weathering, fracture pattern, geomorphological setup and rainfall controls the groundwater occurrence, movement and recharge to aquifers, while the behavior of groundwater level is controlled by physiography, lithology, and rainfall. Granites and gneisses of peninsular gneissic group constitute major aquifers in the urban district. Groundwater occurs in water table/phreatic conditions in the weathered mantle zone of the granitic gneisses and under semi-confined to confined conditions in fractured and jointed rock formations (viz., joints, crevices and cracks of the basement rock). Laterites of Tertiary age occur as isolated patches capping crystalline rocks in Bangalore North taluk and groundwater occur in phreatic condition. Alluvium of $20-\mathrm{m}$ thick occurs along the river courses, though of limited thickness and aerial extent possess substantial groundwater potential.

\section{Materials and methods}

Water sampling: on-site activities

Twelve groundwater sampling stations each around Sankey Tank and Mallathahalli Lake area in the Bangalore North Taluk (Fig. 1) were sampled during pre-monsoon season in the month of April 2012. Addition to this, the surface water samples at three different locations within the Sankey Tank and Mallathahalli Lake were continuously monitored radon activity for every 15 days from March 2012 to May 2012. The groundwater samples from different bore wells were collected after $10 \mathrm{~min}$ of pumping to ensure that the sample collected served as a representative sample, quality wise. Both surface and groundwater samples were collected in a separate special glass vials of $250 \mathrm{~mL}$ capacity, designed for radon-in-water activity measurement ensuring minimum radon loss by degassing (Stringer and Burnett, 2004; Somashekar and Ravikumar 2010) and without any air contact. The collected samples were immediately transported to the laboratory at Department of Environmental Science, Bangalore University for radon analysis.

Analysis of radon: laboratory measurements

Radon concentration in water samples was measured using RAD-7 radon analyzer (Durridge Co., USA) connected to RAD $\mathrm{H}_{2} \mathrm{O}$ accessory with closed loop aeration concept (Lee and Kim 2006). The details of measurement techniques are given elsewhere (Somashekar and Ravikumar 2010). The components of $\mathrm{RAD} \mathrm{H}_{2} \mathrm{O}$ technique are (a) the RAD-7 or radon monitor; (b) the water vial with aerator; (c) the tube of desiccant, supported by the retort stand and (d) aerator assembly. Figure 2 is the schematic representations of the RAD-7 with RAD $\mathrm{H}_{2} \mathrm{O}$ accessory.

The RAD $\mathrm{H}_{2} \mathrm{O}$ method employs a closed loop aeration scheme whereby the air volume and water volume are constant and independent of the flow rate. The operation of this device is based on the principles such as (a) radon is expelled from a water sample using a bubbling kit, (b) expelled radon enters a hemisphere chamber by air circulation, (c) polonium decayed from radon is collected onto a silicon solid-state detector in an high electric field, and (d) radon concentration is estimated from the count rate of polonium (Durridge Co. Inc. 2009).

In the setup, 250-mL sample bottle was connected to RAD-7 detector via bubbling kit and desiccant tube to establish a closed air loop. An internal air pump (with flow rate of about $1 \mathrm{~L} / \mathrm{min}$ ) in the RAD-7 was activated every $5 \mathrm{~min}$ for $1 \mathrm{~min}$ to purge/degass/aerate and circulate radon present in the water into the closed air loop, so that radon released to air stream can finally enter RAD-7 analyzer 
Fig. 2 a Schematic representation of the RAD 7 instrument for measuring radon in water, $\mathbf{b}$ aerator assembly

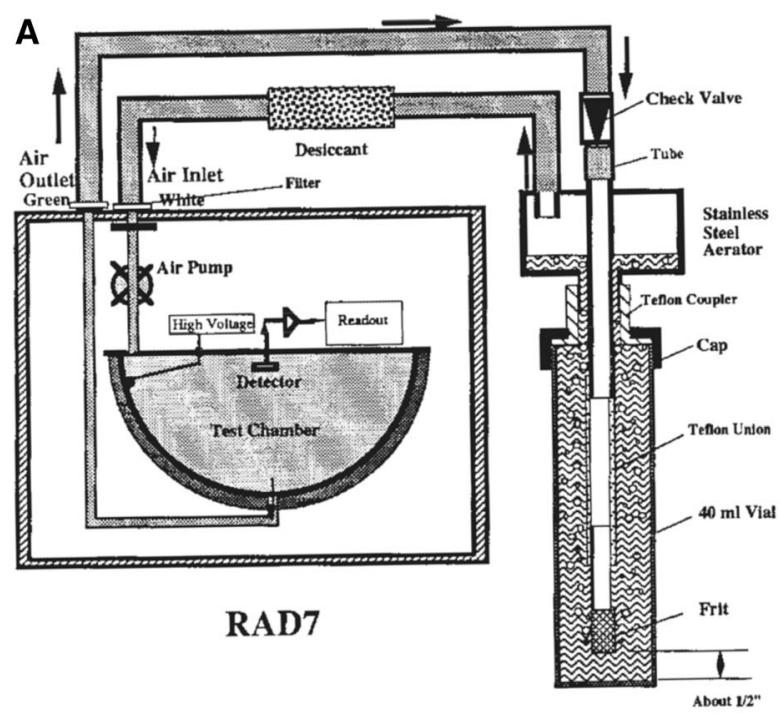

Aerator

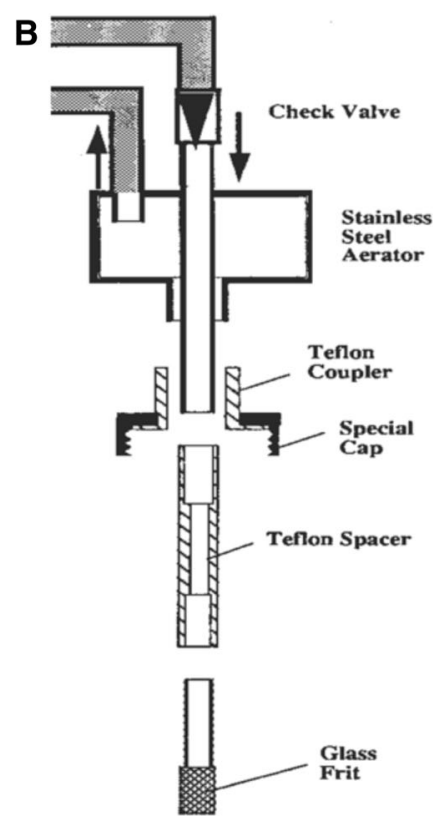

after passing through desiccant tube and air filter. An air filter is used at the entrance of the RAD-7 to prevent dust particles and charged ions from entering the radon chamber. The detection efficiency of the RAD-7 decreases with increase in relative humidity, owing to the neutralization of Po ions by water particles. Hence, $\mathrm{RAD}_{2} \mathrm{O}$ requires that the desiccant, anhydrous $\mathrm{CaSO}_{4}$ (which is commercially sold as Passive Drystick (model no. 12) by Durridge Co.), can be used to maintain humidity at level lower than 6-10\% in the radon chamber and also to dry the air stream before it enters the RAD-7 detector. The air recirculates through the water and continuously extracts the radon until RAD $\mathrm{H}_{2} \mathrm{O}$ system reaches a state of equilibrium because after this no more radon can be extracted from the water. After reaching equilibrium between water and air, the radon activity measured in the air loop was used for calculating the initial radon concentration of the respective water sample. RAD-7 allows determination of radon-in-air activity by detecting alpha decaying radon progenies such as ${ }^{218} \mathrm{Po}^{+}\left(t_{1 / 2}=3.1 \mathrm{~min}\right.$; alpha energy $\left.=6.00 \mathrm{meV}\right)$, ${ }^{216} \mathrm{Po}^{+}\left(t_{1 / 2}=0.15 \mathrm{~s} ; 6.78 \mathrm{meV}\right)$, and ${ }^{214} \mathrm{Po}^{+}\left(t_{1 / 2}=\right.$ $164 \mu \mathrm{s}$; alpha energy $=7.67 \mathrm{meV}$ ) using passivity implanted planar silicon alpha detector (PIPS). The radon monitor (RAD-7) uses a high electric field of 2,000-2,500 V above a silicon semiconductor detected at ground potential to attract/capture the positively charged polonium daughters $\left({ }^{218} \mathrm{Po},{ }^{216} \mathrm{Po}\right.$, and $\left.{ }^{214} \mathrm{Po}\right)$. The alpha detector counts ${ }^{218} \mathrm{Po},{ }^{216} \mathrm{Po}$, and ${ }^{214} \mathrm{Po}$ decay, using their relative energies to discriminate between them as a measure of waterborne ${ }^{222} \mathrm{Rn}$ concentration in air. To ensure the quality control and reliability of the sampling and measurement methods, each sample was analyzed in 4 cycles of 5 min each, with an initial aeration time of $5 \mathrm{~min}$.
Initially, the pump runs for $5 \mathrm{~min}$, aerating the sample and delivering the radon to the RAD-7. The system will wait a further $5 \mathrm{~min}$ and then it starts counting. During the $5 \mathrm{~min}$ of aeration, more than $95 \%$ of the available radon is removed from the water and the components automatically perform everything required to determine the radon concentration in the water. After $5 \mathrm{~min}$, it prints out a shortform report. The same thing is repeated again for $5 \mathrm{~min}$ later, and for two more 5-min periods after that. Thus, radon gas is collected through the energy specific windows, which eliminates interference and maintains very low backgrounds and later counted for the radon concentration. At the end of the run (after the start), the RAD-7 prints out automatically the summary, showing the average radon reading from the four cycles counted, a bar chart of the four readings, and a cumulative spectrum. This procedure takes into account the calibration of the RAD-7, the size of the sample vial, time of the analysis and the total volume of the closed air loop, as set up. Finally, ${ }^{222} \mathrm{Rn}$ activity is expressed in $\mathrm{Bq} / \mathrm{m}^{3}$ (disintegration per second per $\mathrm{m}^{3}$ ) or $\mathrm{Bq} / \mathrm{L}$ (disintegration per second per litre) with $2 \sigma$-uncertainties. All data, except the spectrum, is also stored in memory, and may be printed or downloaded to a PC at any time. The minimum detection limit of RAD-7 for radon in water is approximately $0.4 \mathrm{~Bq} / \mathrm{L}$.

\section{Background sample measurement}

The background sample is not used in the present study as the instrument undergoes calibration each year. There is no need for background sample measurement because of following reasons: the uncontrollable, or "intrinsic", background of the RAD-7 is low enough to ignore in all, but the most 
demanding cases. The intrinsic background of the RAD-7 is less than 1 count per hour, corresponding to a $40-\mathrm{mL}$ water sample concentration of less than $2 \mathrm{pCi} / \mathrm{L}$ or $0.074 \mathrm{~Bq} / \mathrm{L}$ (even lower for the $250-\mathrm{mL}$ sample). In the principle, a background of this low can be accomplished by complete elimination of all radon and its progeny from the system before a measurement with a fair amount of effort and patience. A more realistic background to shoot for in routine analysis might be between 10 and $20 \mathrm{pCi} / \mathrm{L}$ (viz., $0.37-0.74 \mathrm{~Bq} / \mathrm{L}$ ). It is also essential to remember that the background due to purged air radon will change when the air radon concentration changes. Even if we intend to subtract background, one should measure a blank sample at every measurement session. Even if we choose not to use fancy methods to reduce the background, it is necessary to always purge the RAD-7 system between samples. Hence, it is much better to purge with ordinary room air than not to purge at all. In any case, it is also necessary to purge to remove any accumulated water vapor from the system, and bring the relative humidity back down to close to $5 \%$. However, following are some of the methods that can be adopted to reduce the background radon level in the RAD-7 system:

1. The obvious way to reduce background is to purge with very low radon air. Outdoor air rarely exceeds $0.5 \mathrm{pCi} / \mathrm{L}$ (i.e., $0.0185 \mathrm{~Bq} / \mathrm{L}$ ) at several feet above the ground, so one can probably get the water background to below $13 \mathrm{pCi} / \mathrm{L}$ by simply using outdoor air to purge. To get even lower radon in air, a tank or balloon filled with outdoor air and kept for aging for several weeks can be used to purge RAD-7 instrument to bring down the background.

2. The best way to determine the background is to measure a "blank", a water sample containing no radon. Radon free water could be the distilled water available in any local pharmacy or the tap water stored in closed air-tight container undisturbed for 4-week period. The 4-week period allows any radon present in the water to decay away.

3. Another method to reduce background is to use charcoal adsorption to clean the remaining radon from the system following the purge. A small column containing $15 \mathrm{~g}$ of activated carbon can remove up to $98 \%$ of the remaining radon from the RAD $\mathrm{H}_{2} \mathrm{O}$ system when connected in a closed loop. Since water vapor can adversely affect charcoal's capacity to adsorb radon, using it in conjunction with a drying tube can keep the charcoal always dry.

Radon decay correction

If there is any delay in radon analysis or if a sample is taken and analyzed some time later (rather than immediately), the sample's radon concentration will decline due to the radioactive decay. Hence, it is essential that the resulting activity concentrations were decay-corrected back from the time the sample was drawn (time of sampling) to the time the sample was counted. Decay correction can be used for samples counted up to 10 days after sampling though analytical precision will decline as the sampler gets weaker and weaker (Durridge Co. Inc. 2009). The decay correction is a simple exponential function with a time constant of $132.4 \mathrm{~h}$. The time elapsed for the sample collection and analysis will corrected using the equation

$C=C_{0} e^{-\lambda t}$

where $C=$ measured concentration, $C_{0}=$ initial concentration (to be calculated after the decay correction), $t=$ time elapsed since collection (days).

Usually decay correction is required to correct the radon result back to the sampling time. However, in the present study, the collected samples were immediately analyzed after the collection without any delay and hence decay correction was not calculated.

Appraisal of radiation dose to individuals of different age groups

Radiological effects owing to ingestion of dissolved radon in drinking water are defined in terms of effective radiation dose received by the population during habitual consumption of water. Dose coefficients (DCs) are committed effective doses per unit intake in units of $\mathrm{Sv} / \mathrm{Bq}$. The committed effective dose is the sum of the products of the committed organ or tissue equivalent doses and the appropriate organ or tissue-weighting factors. The dose is integrated over a time period following the intake. The integration time is 50 years for adults and from intake to age 70 years for children. Six age groups were considered as shown in Table 1. In calculating doses from drinking water intake, average annual water consumption rates (ACR) for public (IAEA 1996) were used for children and youths. However, an adult value of $2 \mathrm{~L} /$ day ( $730 \mathrm{~L} /$ year)

Table 1 ICRP age groups and their ACRs (IAEA 1996)

\begin{tabular}{llll}
\hline $\begin{array}{l}\text { Age } \\
\text { group }\end{array}$ & $\begin{array}{l}\text { Age range } \\
\text { (years) }\end{array}$ & $\begin{array}{l}\text { Water consumption } \\
\text { (L/day) }\end{array}$ & $\begin{array}{l}\text { Water consumption } \\
\text { (L/year) }\end{array}$ \\
\hline 3 months & $0-1$ & 0.55 & 200 \\
1 year & $1-2$ & 0.71 & 260 \\
5 year & $2-7$ & 0.82 & 300 \\
10 year & $7-12$ & 0.96 & 350 \\
15 year & $12-17$ & 1.64 & 600 \\
Adult & $>17$ & 2.00 & 730 \\
\hline
\end{tabular}




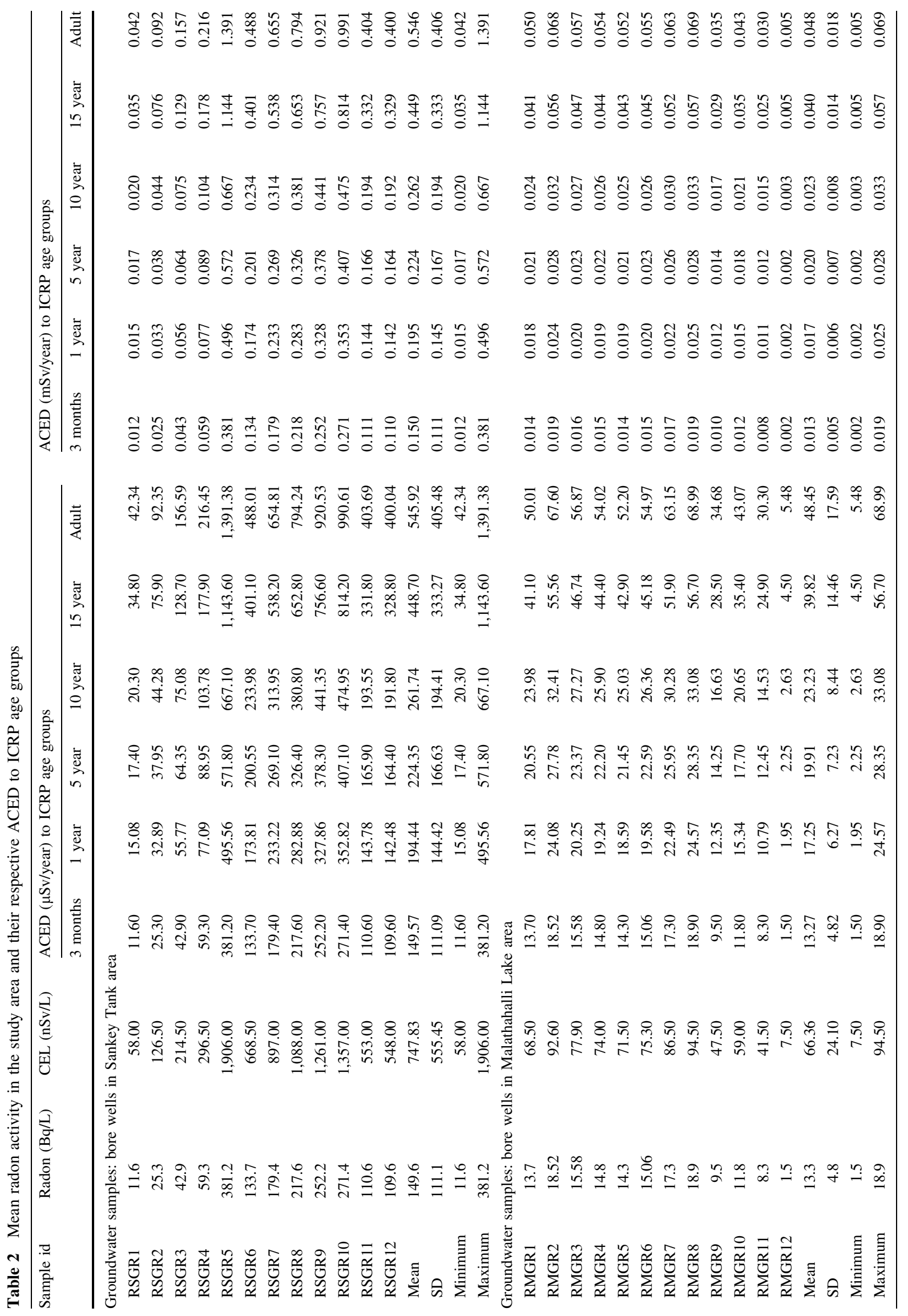




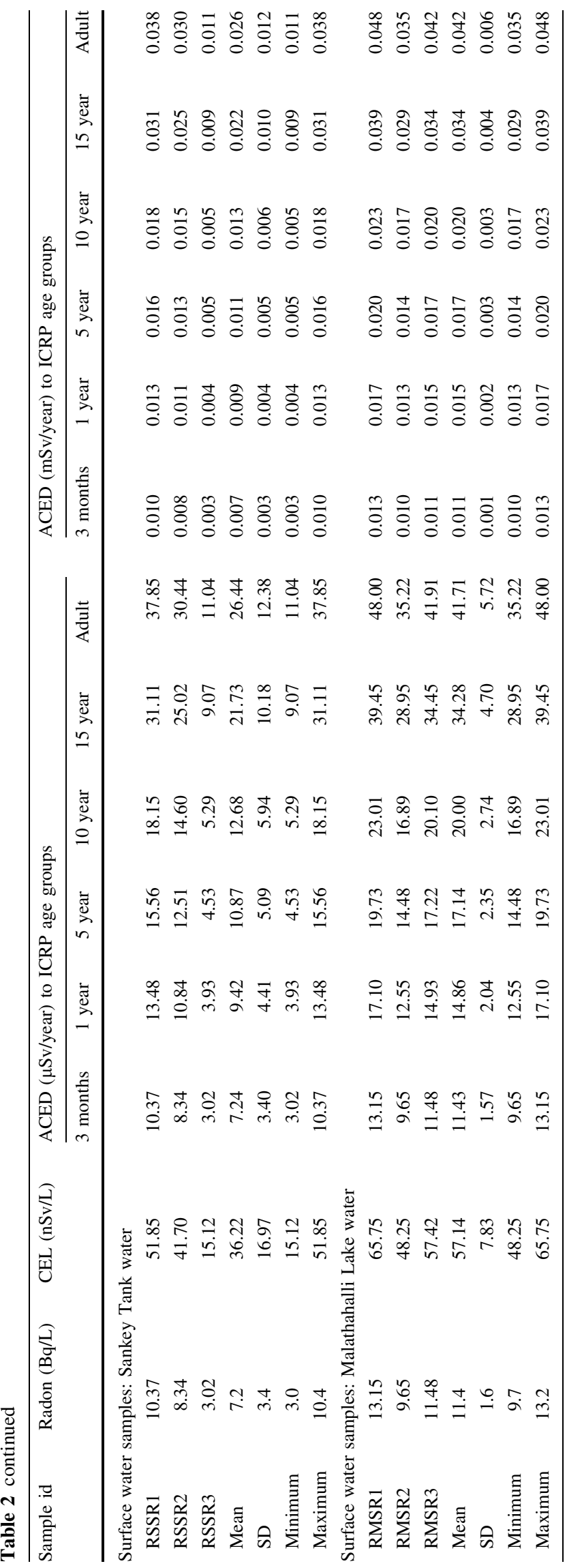

was used here for consistency with most international drinking water guidelines (Cevik et al. 2006).

Annual committed effective dose (ACED) is the activity that enters the respiratory or gastrointestinal tract from the environment. Though, dose calculations based on current age-specific (ICRP 1996) and nuclides-specific (IAEA 1996) dose conversion coefficients for ingestion are available, the ingested dose conversion factor of $5 \times 10^{-9}$ Sv/Bq for ${ }^{222} \mathrm{Rn}$ nuclide (UNSCEAR 1993) and different age groups (IAEA 1996) were used for calculation purpose in the present case. The dose is expressed in terms of sievert or microsievert or millisievert per year. In the present study, the ACED received from ingestion of water (Table 1) containing radon to an individual consumer under ICRP age groups is evaluated using the equation:

$$
\begin{aligned}
\operatorname{Dose}(\mathrm{Sv})= & \text { radon activity concentration }(\mathrm{Bq} / \mathrm{L}) \\
& \times \text { annual water consumption }(\mathrm{L}) \\
& \times \text { dose conversion factor }(\mathrm{Sv} / \mathrm{Bq})
\end{aligned}
$$

Evaluation of radiation dose to internal organs

The radon concentration of drinking water is an important issue from the dosimetry aspect, because additional attention is paid to the control of public natural radiation exposure. Regarding radiation dose to the public, due to waterborne radon, it was believed that waterborne radon may cause higher risk than all other contaminants in water (Vitz 1991). Radon enters human body through ingestion and inhalation (when radon is released from water to indoor air). Therefore, radon in water is a source of radiation dose to both stomach and lungs. The annual effective doses for ingestion and inhalation were calculated according to the parameters introduced by United Nations Scientific Committee on the Effects of Atomic Radiation's report (UNSCEAR 2000).

For ingestion, the following parameters were used:

- The effective dose coefficient from ingestion equals $3.5 \mathrm{nSv} /(\mathrm{BqL})$.

- Annual intakes by infants, children, and adults are found to be about 100, 75, and 50 litres, respectively.

- The annual effective doses, due to ingestion corresponding to $1 \mathrm{~Bq} / \mathrm{L}$, would equal $0.35 \mu \mathrm{Sv} /$ year for infants, $0.26 \mu \mathrm{Sv} /$ year for children, and $0.18 \mu \mathrm{Sv} /$ year for adults.

For inhalation, the following parameters were used:

- Ratio of radon in air to radon in tap water supply is in the range of 4-10 (i.e., $10^{-4}$ )

- Average indoor occupancy time per person is about 7,000 h/year.

- UNSCEAR (1993) specified a worldwide equilibrium factor between radon and its progeny for indoor environment is equal to 0.4 . 
- Dose conversion factor for radon exposure is $9 \mathrm{nSv} /$ $\left(\mathrm{Bq} \cdot \mathrm{hm}^{3}\right)$.

The factor (viz., 0.4) prescribed by UNSCEAR (1993) has been employed by several researchers in Asian subcontinent (viz., Chandrashekara et al. 2012; Khattak et al. 2011) as well as across the world (Binesh et al. 2010; Mowlavi et al. 2012; Németh et al. 2006; Nikolov et al. 2011; Pourhabib et al. 2011; Tayyeb et al. 1998; Yamada et al. 2006). Hence, the same equilibrium factor was employed in the present study also as its measurement was not attempted. The annual effective dose due to inhalation corresponding to the concentration of $1 \mathrm{~Bq} / \mathrm{L}$ in tap water is $2.5 \mu \mathrm{Sv} /$ year. Therefore, waterborne radon concentration of $1 \mathrm{~Bq} / \mathrm{L}$ causes total effective dose of about $2.68 \mu \mathrm{Sv} /$ year for adults.

\section{Results and discussion}

Tables 2 gives the results obtained for the mean radon activity concentrations in various water samples analyzed along with their respective committed effective dose per litre (CEL) and age-dependent ACED to the individual belonging to different ICRP age groups assuming annual consumption of the estimated volumes of water (ACR). The distribution of radon in the ground and surface water and their respective committed effective doses is summarized in Fig. 3. Table 3 summarizes the radon measurements in other parts of the world for comparison. Table 4 presents ACED to internal organs such as stomach and lungs due to ingestion of radon in water and inhalation of air having radon released from water.

Currently, the ${ }^{222} \mathrm{Rn}$ concentration in drinking water is not regulated. But, the Safe Drinking Water Act directs the United States Environmental Protection Agency (USEPA) to propose and finalize a maximum contaminant level (MCL) for radon in drinking water and also to make available a higher alternative maximum contaminant level (AMCL) accompanied by a multimedia mitigation (MMM) program to address radon risks in indoor air. The proposed EPA's MCL is $11.1 \mathrm{~Bq} / \mathrm{L}\left(300 \mathrm{pCi} / \mathrm{L}\right.$ or $\left.11.1 \mathrm{kBq} / \mathrm{m}^{3}\right)$ (Barnett et al. 1995; Somashekar and Ravikumar 2010), while the proposed AMCL is $146 \mathrm{~Bq} / \mathrm{L}$ (EPA 1991) and/or $150 \mathrm{~Bq} / \mathrm{L}$ (Zhuo et al. 2001). In Contrast to this, the
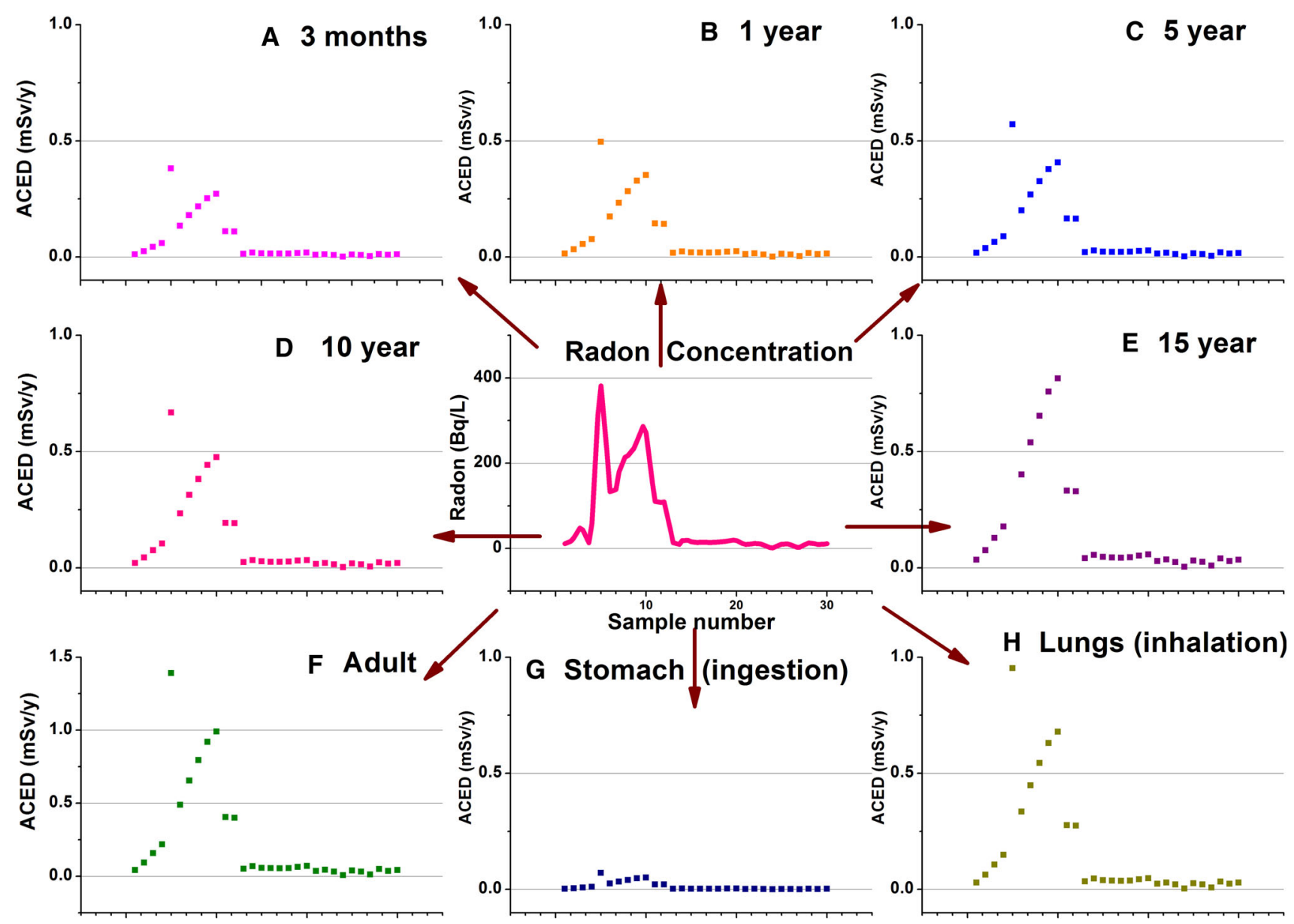

Fig. 3 Variation in mean radon activity and their respective ACED values to ICRP age groups and internal organs 
Table 3 Radon activity in water in other parts of the world

\begin{tabular}{|c|c|c|c|c|}
\hline \multirow[t]{2}{*}{ Area } & \multicolumn{3}{|c|}{${ }^{222} \mathrm{Rn}$ concentration $(\mathrm{Bq} / \mathrm{L})$} & \multirow[t]{2}{*}{ Source } \\
\hline & Min & Max & Average & \\
\hline Markandeya river basin, India & 2.21 & 27.3 & 9.30 & \multirow{2}{*}{$\begin{array}{l}\text { Somashekar and } \\
\text { Ravikumar (2010) }\end{array}$} \\
\hline Varahi river basin, India & 0.20 & 10.10 & 2.07 & \\
\hline Mysore City, India & 4.25 & 435.00 & - & $\begin{array}{l}\text { Chandrashekara et al. } \\
\text { (2012) }\end{array}$ \\
\hline Kumaun Himalayan region, India & 1.00 & 392.0 & - & Bourai et al. (2012) \\
\hline Kamuan, India & 1.00 & 336 & - & Yogesh, et al. (2009) \\
\hline Islamabad, Pakistan & - & - & 88.63 & Ali et al. (2010) \\
\hline Abmadan river, Javaherdeh, Iran & - & - & 21.29 & Pourhabib et al. (2011) \\
\hline Balakot and Manshera, Pakistan & 4.99 & 24.52 & 15.52 & Khan et al. (2010) \\
\hline Virginia and Maryland, U.S. & 3.70 & 296.00 & - & Mose et al. (1990) \\
\hline Amasya, turkey & 0.32 & 2.72 & - & Oner et al. (2009) \\
\hline Baoji, China & 12.00 & 127.00 & - & Xinwei (2006) \\
\hline Penang, Malaysia & 0.49 & 26.26 & 25.00 & Muhammad et al. (2012) \\
\hline Wells, southern Poland & - & - & 207 & Kusyk and Ciesla (2002) \\
\hline Mashhad city of Iran & - & - & 16.24 & Binesh et al. (2010) \\
\hline Milano areas, Northern Italy & - & - & 6.80 & Rusconi et al. (2004) \\
\hline $\begin{array}{l}\text { Aqua Viva } 0.51 \text { natural water (bottled } \\
\text { water), Novi Sad }\end{array}$ & - & - & 1,46 & Nikolov et al. (2011) \\
\hline Sankey Tank area, India & 11.60 & 381.20 & - & This study \\
\hline Mallathahalli Lake area, India & 1.50 & 18.90 & - & This study \\
\hline
\end{tabular}

European Union (EU) Commission issued a non-binding recommendation in 2001 on the protection of the public against exposure to radon in drinking water supplies (2001/ 928/Erratum). Accordingly, it recommends an action/reference level of $100 \mathrm{~Bq} / \mathrm{L}$ for public or commercial drinking water supplies and $1,000 \mathrm{~Bq} / \mathrm{L}$ for individual or private water supplies. Remedial action is always justified/warranted for water supplies with radon above 1,000 Bq/L (EU 2001a, b; WHO 2008). Even the World Health Organization (WHO 2008) has recommended a treatment level of $100 \mathrm{~Bq} / \mathrm{L}$ for radon in drinking water supplies.

\section{Variation in radon concentration}

The mean radon activity ranged from $11.6 \pm 1.7 \mathrm{~Bq} / \mathrm{L}$ to $381.2 \pm 2 \mathrm{~Bq} / \mathrm{L}$ in the twelve groundwater samples in the Sankey Tank area, with all the samples exceeding the MCL value of $11.1 \mathrm{~Bq} / \mathrm{L}$ prescribed by USEPA (1991). Contrast to this, mean radon activity varied from $1.50 \pm 0.83 \mathrm{~Bq} / \mathrm{L}$ to $18.9 \pm 1.59 \mathrm{~Bq} / \mathrm{L}$ in the twelve groundwater samples in the Mallathahalli Lake area (Table 2), with $75 \%$ of the samples exceeding the MCL of $11.1 \mathrm{~Bq} / \mathrm{L}$. Of the remaining $25 \%$ of the groundwater samples in the Mallathahalli Lake area, two samples showed radon concentration very close to MCL value (viz., 8.3 and $9.5 \mathrm{~Bq} / \mathrm{L}$ ) and one sample had very low radon activity of $1.5 \mathrm{~Bq} / \mathrm{L}$ (Table 2). It is also apparent that the levels of measured radon in $66.67 \%$ of samples around Sankey Tank area exceeded the reference level of $100 \mathrm{~Bq} / \mathrm{L}$ recommended by WHO (2008) and EU (2001a, b).

The mean radon activity in the surface water samples collected at three different sites within the Sankey Tank and Mallathahalli Lake was $7.24 \pm 1.48 \mathrm{~Bq} / \mathrm{L}$ and $11.43 \pm$ $1.11 \mathrm{~Bq} / \mathrm{L}$, respectively. Mallathahalli Lake water showed higher radon values above the EPA's MCL value compared to the Sankey Tank water (Table 2). However, Sankey Tank and Mallathahalli Lake water showed radon concentration below the WHO and EU's reference value of $100 \mathrm{~Bq} / \mathrm{L}$.

The mean radon concentration obtained in the present study were very high compared to that reported by Somashekar and Ravikumar (2010) in the Varahi river basin, Udupi district $(0.2 \pm 0.4$ to $10.1 \pm 1.7 \mathrm{~Bq} / \mathrm{L})$ and Markandeya river basin, Belgaum district $(2.21 \pm 1.66$ to $27.3 \pm 0.787 \mathrm{~Bq} / \mathrm{L}$ ) in Karnataka State, India. Binesh et al. (2010) reported mean radon concentrations in the water samples used for drinking and other household uses in Mashhad city of Iran to vary from 0.064 to $46.088 \mathrm{~Bq} / \mathrm{L}$ with a mean value of $16.238 \pm 9.322 \mathrm{~Bq} / \mathrm{L}$, while Nikolov et al. (2011) recorded the radon concentration in Novi Sad to vary from 3.9 to $18.6 \mathrm{~Bq} / \mathrm{L}$ in public drink fountains and 0.75 to $1,463 \mathrm{~Bq} / \mathrm{L}$ in bottled drinking water and tap water. Similarly, Xinwei and Xiaolan (2004) reported variation in radon concentrations in tap and well water used for drinking purposes from three main cities (viz., Xi'an, 
Table 4 ACED to internal organs

\begin{tabular}{|c|c|c|c|c|c|c|c|}
\hline \multirow[t]{2}{*}{ Sample id } & \multirow[t]{2}{*}{ Radon $(\mathrm{Bq} / \mathrm{L})$} & \multicolumn{2}{|c|}{ Stomach (ingestion) } & \multicolumn{2}{|c|}{ Lung (inhalation) } & \multicolumn{2}{|c|}{ Whole body } \\
\hline & & $\mu \mathrm{Sv} / \mathrm{year}$ & $\mathrm{mSv} / \mathrm{year}$ & $\mu \mathrm{Sv} / \mathrm{year}$ & mSv/year & $\mu \mathrm{Sv} / \mathrm{year}$ & $\mathrm{mSv} / \mathrm{year}$ \\
\hline \multicolumn{8}{|c|}{ Groundwater samples: bore wells around Sankey Tank area } \\
\hline RSGR1 & 11.60 & 2.18 & 0.0022 & 29.00 & 0.0290 & 31.18 & 0.031 \\
\hline RSGR2 & 25.30 & 4.74 & 0.0047 & 63.25 & 0.0633 & 67.99 & 0.068 \\
\hline RSGR3 & 42.90 & 8.04 & 0.0080 & 107.25 & 0.1073 & 115.29 & 0.115 \\
\hline RSGR4 & 59.30 & 11.12 & 0.0111 & 148.25 & 0.1483 & 159.37 & 0.159 \\
\hline RSGR5 & 381.20 & 71.48 & 0.0715 & 953.00 & 0.9530 & $1,024.48$ & 1.024 \\
\hline RSGR6 & 133.70 & 25.07 & 0.0251 & 334.25 & 0.3343 & 359.32 & 0.359 \\
\hline RSGR7 & 179.40 & 33.64 & 0.0336 & 448.50 & 0.4485 & 482.14 & 0.482 \\
\hline RSGR8 & 217.60 & 40.80 & 0.0408 & 544.00 & 0.5440 & 584.80 & 0.585 \\
\hline RSGR9 & 252.20 & 47.29 & 0.0473 & 630.50 & 0.6305 & 677.79 & 0.678 \\
\hline RSGR10 & 271.40 & 50.89 & 0.0509 & 678.50 & 0.6785 & 729.39 & 0.729 \\
\hline RSGR11 & 110.60 & 20.74 & 0.0207 & 276.50 & 0.2765 & 297.24 & 0.297 \\
\hline RSGR12 & 109.60 & 20.55 & 0.0206 & 274.00 & 0.2740 & 294.55 & 0.295 \\
\hline \multicolumn{8}{|c|}{ Groundwater samples: bore wells around Malathahalli Lake area } \\
\hline RMGR1 & 13.70 & 2.57 & 0.0026 & 34.25 & 0.0343 & 36.82 & 0.037 \\
\hline RMGR2 & 18.52 & 3.47 & 0.0035 & 46.30 & 0.0463 & 49.77 & 0.050 \\
\hline RMGR3 & 15.58 & 2.92 & 0.0029 & 38.95 & 0.0390 & 41.87 & 0.042 \\
\hline RMGR4 & 14.80 & 2.78 & 0.0028 & 37.00 & 0.0370 & 39.78 & 0.040 \\
\hline RMGR5 & 14.30 & 2.68 & 0.0027 & 35.75 & 0.0358 & 38.43 & 0.038 \\
\hline RMGR6 & 15.06 & 2.82 & 0.0028 & 37.65 & 0.0377 & 40.47 & 0.040 \\
\hline RMGR7 & 17.30 & 3.24 & 0.0032 & 43.25 & 0.0433 & 46.49 & 0.046 \\
\hline RMGR8 & 18.90 & 3.54 & 0.0035 & 47.25 & 0.0473 & 50.79 & 0.051 \\
\hline RMGR9 & 9.50 & 1.78 & 0.0018 & 23.75 & 0.0238 & 25.53 & 0.026 \\
\hline RMGR10 & 11.80 & 2.21 & 0.0022 & 29.50 & 0.0295 & 31.71 & 0.032 \\
\hline RMGR11 & 8.30 & 1.56 & 0.0016 & 20.75 & 0.0208 & 22.31 & 0.022 \\
\hline RMGR12 & 1.50 & 0.28 & 0.0003 & 3.75 & 0.0038 & 4.03 & 0.004 \\
\hline \multicolumn{8}{|c|}{ Surface water samples: Sankey Tank water } \\
\hline RSSR1 & 10.37 & 1.94 & 0.0019 & 25.93 & 0.0259 & 27.87 & 0.028 \\
\hline RSSR2 & 8.34 & 1.56 & 0.0016 & 20.85 & 0.0209 & 22.41 & 0.022 \\
\hline RSSR3 & 3.02 & 0.57 & 0.0006 & 7.56 & 0.0076 & 8.13 & 0.008 \\
\hline \multicolumn{8}{|c|}{ Surface water samples: Malathahalli Lake water } \\
\hline RMSR1 & 13.15 & 2.47 & 0.0025 & 32.88 & 0.0329 & 35.34 & 0.035 \\
\hline RMSR2 & 9.65 & 1.81 & 0.0018 & 24.13 & 0.0241 & 25.93 & 0.026 \\
\hline RMSR3 & 11.48 & 2.15 & 0.0022 & 28.71 & 0.0287 & 30.86 & 0.031 \\
\hline
\end{tabular}

Xianyang, and Baoji) of Shaanxi Province, China, respectively, to vary from 4.10 to $9.53,7.52$ to 54.72 , and 6.28 to $106.47 \mathrm{KBq} / \mathrm{m}^{3}$.

Table 3 provides minimum, maximum, and mean radon activity concentration in other parts of the world for comparison. When results of present study were compared with values from other parts of the world, similar results can be seen in Mysore, Kamuan, and Kumaun Himalayan regions in India; Islamabad in Pakistan; Virginia and Maryland, USA; Baoji, China; Southern Poland and bottled mineral waters in Novi Sad. Further, the present results around Sankey Tank area were remarkably higher than those reported in Amasya, Turkey; Balakot and Manshera, Pakistan; Abmadan river, Javaherdeh, Iran; Penang, Malaysia; Milano areas, Northern Italy.

Evaluation of mean annual radon dose

The World Health Organization (WHO 1993, 2004) and the EU Council (EUC 1998) recommended the determination of reference level of the annual effective dose received from drinking water consumption at $0.1 \mathrm{mSv} / \mathrm{year}$ from these three radioisotopes: ${ }^{222} \mathrm{Rn},{ }^{3} \mathrm{H},{ }^{4} \mathrm{~K}$ (Somlai et al. 2007) while, UNSCEAR (2000) and WHO (1993) recommended a 
dose limit for members of the public as $1 \mathrm{mSv} / \mathrm{year}$. Calculated values of minimum, maximum, and mean committed effective doses per litre (nSv/L) and annual committed effective doses ( $\mu \mathrm{Sv} /$ year and $\mathrm{mSv} /$ year) for different ICRP age groups based on varying average ACR of ground and surface waters and ${ }^{222} \mathrm{Rn}$ activities are summarized in Table 2. Since, radon enters human body via ingestion as well as inhalation (as radon released from water to air), the annual committed effective doses to internal organs such as stomach and lungs was also evaluated (Table 4).

\section{Committed effective dose per litre}

The CEL ranged from 58.0 to $1,906 \mathrm{nSv} / \mathrm{L}$ (mean value $747.83 \pm 555.45 \mathrm{nSv} / \mathrm{L}$ ) to 7.50 to $94.5 \mathrm{nSv} / \mathrm{L}$ (mean value $66.36 \pm 24.1 \mathrm{nSv} / \mathrm{L})$, respectively, in the groundwater samples in Sankey Tank and Mallathahalli Lake areas. It is apparent that the CEL in the groundwater in Sankey Tank area are higher than that in the Mallathahalli Lake area. The CEL ranged from 15.12 to $51.85 \mathrm{nSv} / \mathrm{L}$ (mean $36.22 \pm 16.97 \mathrm{nSv} / \mathrm{L}$ ) to 48.25 to $65.75 \mathrm{nSv} / \mathrm{L}$ (mean $57.14 \pm 7.83 \mathrm{nSv} / \mathrm{L}$ ), respectively, in the Sankey Tank and Mallathahalli Lake waters.

\section{Annual committed effective dose}

ACED to ICRP age groups (Table 1) depending on their average ACR are detailed below keeping in mind that these are annual doses to children relative to adults when the same source of water was consumed by various age groups.

For the ICRP age groups of 3 months with age ranging from 0 to 1 year and having mean annual water ingestion of $200 \mathrm{~L}$, the ACED values ranged from 0.012 to $0.381 \mathrm{mSv} /$ year with a mean value of $0.150 \pm 0.111 \mathrm{mSv} /$ year for the groundwater samples in Sankey Tank area; $0.002-0.019 \mathrm{mSv} / \mathrm{year}$ with a mean value of $0.013 \pm$ $0.005 \mathrm{mSv} / y e a r$ for the groundwater samples in Mallathahalli Lake area; 0.003-0.010 mSv/year with an average value of $0.007 \pm 0.003 \mathrm{mSv} /$ year for Sankey Tank water and $0.010-0.013 \mathrm{mSv} /$ year with an average value of $0.011 \pm 0.001 \mathrm{mSv} /$ year for Mallathahalli Lake water (Fig. 3a). The overall dose rate received by ICRP age group of 3 months being less than $0.381 \mathrm{mSv} / \mathrm{year}$, was very less compared to the UNSCEAR and WHO recommended limit of $1 \mathrm{mSv} /$ year for public.

For the ICRP age groups of 1 year with age ranging from 1 to 2 years and having mean annual water consumption of 260 $\mathrm{L}$, the ACED values varied from 0.015 to $0.496 \mathrm{mSv} / \mathrm{year}$ with an average value of $0.195 \pm 0.145 \mathrm{mSv} / \mathrm{year}$ for the groundwater samples in Sankey Tank area; 0.002-0.025 $\mathrm{mSv} / y e a r$ with a mean value of $0.017 \pm 0.006 \mathrm{mSv} / \mathrm{year}$ for the groundwater samples in Mallathahalli Lake area;
0.004-0.013 $\mathrm{mSv} /$ year with an average value of $0.009 \pm$ $0.004 \mathrm{mSv} / y e a r$ for Sankey Tank water and 0.013-0.017 $\mathrm{mSv} /$ year with a mean value of $0.015 \pm 0.002 \mathrm{mSv} /$ year for Mallathahalli Lake water (Fig. 3b). The complete dose rate received by ICRP age group of 1 year is less than $0.496 \mathrm{mSv} /$ year, well below the UNSCEAR and WHO recommended limit of $1 \mathrm{mSv} /$ year for public.

For the ICRP age groups of 5 years with age ranging from 2 to 7 years and having mean annual water intake of $300 \mathrm{~L}$, the ACED values range from 0.017 to $0.572 \mathrm{mSv} / \mathrm{year}$ with a mean value of $0.224 \pm 0.167 \mathrm{mSv} /$ year for the groundwater samples in Sankey Tank area; 0.002-0.028 mSv/year with an average value of $0.020 \pm 0.007 \mathrm{mSv} /$ year for the groundwater samples in Mallathahalli Lake area; 0.005-0.016 mSv/year with a mean value of $0.011 \pm 0.005 \mathrm{mSv} / \mathrm{year}$ for Sankey Tank water and $0.014-0.020 \mathrm{mSv} /$ year with an average value of $0.017 \pm 0.003 \mathrm{mSv} /$ year for Mallathahalli Lake water (Fig. 3c). The total dose rate received by ICRP age group of 5 years is less than $0.572 \mathrm{mSv} /$ year, well below the UNSCE$\mathrm{AR}$ and $\mathrm{WHO}$ recommended limit of $1 \mathrm{mSv} / \mathrm{year}$ for public.

For the ICRP age groups of 10 years with age ranging from 7 to 12 years and having mean annual water sipping of $350 \mathrm{~L}$, the ACED values vary from 0.020 to $0.667 \mathrm{mSv} /$ year with a mean value of $0.262 \pm 0.194 \mathrm{mSv} / \mathrm{year}$ for the groundwater samples in Sankey Tank area; 0.003-0.033 $\mathrm{mSv} /$ year with an average value of $0.023 \pm 0.008 \mathrm{mSv} /$ year for the groundwater samples in Mallathahalli Lake area; $0.005-0.018 \mathrm{mSv} / \mathrm{year}$ with a mean value of $0.013 \pm$ $0.006 \mathrm{mSv} / \mathrm{year}$ for Sankey Tank water and 0.017-0.023 $\mathrm{mSv} /$ year with an average value of $0.020 \pm 0.003 \mathrm{mSv} /$ year for Mallathahalli Lake water (Fig. 3d). The overall dose rate received by ICRP age group of 10 years was $<0.667 \mathrm{mSv} /$ year, which is below the UNSCEAR and WHO recommended limit of $1 \mathrm{mSv} /$ year for public.

For the ICRP age groups of 15 years with age ranging from 12 to 17 years and having a mean annual water feeding of $600 \mathrm{~L}$, the ACED values range from 0.035 to $1.144 \mathrm{mSv} /$ year with an average value of $0.449 \pm 0.333$ $\mathrm{mSv} / \mathrm{year}$ for the groundwater samples in Sankey Tank area; $0.005-0.057 \mathrm{mSv} / \mathrm{year}$ with a mean value of $0.040 \pm$ $0.014 \mathrm{mSv} / y e a r$ for the groundwater samples in Mallathahalli Lake area; $0.009-0.031 \mathrm{mSv} /$ year with an average value of $0.022 \pm 0.010 \mathrm{mSv} /$ year for Sankey Tank water and $0.029-0.039 \mathrm{mSv} / \mathrm{year}$ with a mean value of $0.034 \pm$ $0.004 \mathrm{mSv} / y e a r$ for Mallathahalli Lake water. The complete dose rate received by ICRP age group of 15 years was well below the UNSCEAR and WHO recommended limit of $1 \mathrm{mSv} /$ year for public except for one groundwater sample from Sankey tank area (viz., 1.144 mSv/year) (Fig. 3e).

For the ICRP age groups of adult category with age above 17 years and ingesting mean annual water of $730 \mathrm{~L}$, the ACED values vary from 0.042 to $1.391 \mathrm{mSv} /$ year with a mean value of $0.546 \pm 0.406 \mathrm{mSv} / \mathrm{year}$ for the groundwater 
samples in Sankey Tank area; 0.005-0.069 mSv/year with an average value of $0.048 \pm 0.018 \mathrm{mSv} / \mathrm{year}$ for the groundwater samples in Mallathahalli Lake area; 0.011-0.038 mSv/ year with a mean value of $0.026 \pm 0.012 \mathrm{mSv} / \mathrm{year}$ for Sankey Tank water and $0.035-0.048 \mathrm{mSv} / \mathrm{year}$ with an average value of $0.042 \pm 0.006 \mathrm{mSv} / \mathrm{year}$ for Mallathahalli Lake water. The total dose rate received by ICRP age group of adult category is well below the UNSCEAR and WHO recommended limit of $1 \mathrm{mSv} / \mathrm{year}$ for public except for three groundwater samples from Sankey tank area. In these three samples, the ACED values were either very close to (viz., 0.92 and $0.99 \mathrm{mSv} / \mathrm{year})$ or above $(1.39 \mathrm{mSv} / \mathrm{year})$ the recommended limit (Fig. 3f).

It is evident from the present study that the ACED value was increasing with increase in radon activity, age and water consumption rates. The ACED received by ICRP age group of adult category $>$ ICRP age group of 15 year$\mathrm{s}>$ ICRP age group of 10 years $>$ ICRP age group of 5 years $>$ ICRP age group of 1 year $>$ ICRP age group of 3 months. In a similar approach by Jing Chen (2010) to estimate DCs to ICRP age groups based on ACRs for Canadian populations, it was resolved that though children drink less water than adults, ACEDs received by children were still significantly higher (nearly 10-11 times) than that of adults for many radionuclides in drinking water. $\mathrm{He}$ also opined that similar results could be obtained for consumptions of various foodstuffs, such as fresh liquid milk, other commercial foods and beverages.

The overall average ACED value from radon emanating from water received by an individual depending upon their ACRs in the study area was significantly lower than the UNSCEAR and WHO recommended limit for public of $1 \mathrm{mSv} /$ yearear except for few samples in Sankey Tank area. The dose rates due to ingestion of radon in drinking water in the present study are very high compared to the dose to general public gathered by Somashekar and Ravikumar (2010) in the Varahi river basin $(0.73-36.87 \mu \mathrm{Sv} /$ year) and Markandeya river basin (8.07-99.65 $\mu \mathrm{Sv} /$ year), respectively, in Udupi and Belgaum districts of Karnataka State, India. In Contrast to this, Xinwei and Xiaolan (2004) studied drinking water radon effective dose rates to males and females due to ingestion of tap and well water used for drinking purposes from three main cities namely, Xi'an, Xianyang, and Baoji of Shaanxi Province, China and found that that the mean annual effective dose equivalent from drinking water radon to male and female, respectively, varying from 0.068 to $0.457 \mathrm{mSv} / \mathrm{year}$ and 0.060 to $0.402 \mathrm{mSv} / \mathrm{year}$.

ACED to internal organs like stomach and lungs

Radon gas being a volatile gas, mildly soluble in water, tends to leave the water upon contact with air. The rate of radon transfer from water to air increases with temperature, agitation, mixing, and surface area. In household water usage, showers, baths, dishwashers, laundries, and toilets all provide adequate aeration to release a high percentage of the water's radon content into household air (Prichard 1987). In principle, the radon will continue to be released from water as the aeration process continues, until a state of equilibrium develops. Radon in water is a source of radiation dose to both stomach and lungs as it can enter human body via ingestion and through inhalation. Hence, an attempt has been made in the present study to illustrate the radiation dose received by stomach and lungs.

The ACED values received by stomach due to ingestion of waterborne radon varied from 2.18 to $71.48 \mu \mathrm{Sv} /$ year with a mean value of $28.04 \pm 20.39 \mu \mathrm{Sv} /$ year for the groundwater samples in Sankey Tank area; 0.28-3.54 $\mu \mathrm{Sv} /$ year with an average value of $2.49 \pm 0.88 \mu \mathrm{Sv} /$ year for the groundwater samples in Mallathahalli Lake area; 0.57-1.94 $\mu \mathrm{Sv} /$ year with a mean value of $1.36 \pm 0.58 \mu \mathrm{Sv} / \mathrm{year}$ for Sankey Tank water and 1.81-2.47 $\mu \mathrm{Sv} /$ year with an average value of $2.14 \pm 0.268 \mu \mathrm{Sv} / \mathrm{year}$ for Mallathahalli Lake water. The total dose rate received by stomach due to ingestion of radon in water was less than $71.48 \mu \mathrm{Sv} /$ year (Table 4 ), which is very negligible compared to UNSCEAR and $\mathrm{WHO}$ recommended limit of $1 \mathrm{mSv} / \mathrm{year}$ for public.

In contrast, the ACED values received by lungs due to inhalation of waterborne radon released into air varied from 29.00 to $953.0 \mu \mathrm{Sv} / \mathrm{year}$ with a mean value of $373.92 \pm 271.88 \mu \mathrm{Sv} / \mathrm{year}$ for the groundwater samples in Sankey Tank area; $3.75-47.25 \mu$ Sv/year with an average value of $33.18 \pm 11.80 \mu \mathrm{Sv} / \mathrm{year}$ for the groundwater samples in Mallathahalli Lake area; 7.56-25.93 $\mu$ Sv/year with a mean value of $18.11 \pm 7.74 \mu \mathrm{Sv} /$ year for Sankey Tank water and 24.13-32.88 $\mu \mathrm{Sv} /$ year with an average value of $28.57 \pm 3.574 \mu \mathrm{Sv} / \mathrm{year}$ for Mallathahalli Lake water. It is evident that the ACED value received by lungs due to inhalation of radon in air (which is released from water) was on the higher side compared to that received by stomach wall due to ingestion of waterborne radon (Table 4). Thus, it can be inferred that there is more chance for bronchial epithelium to become cancerous than cells in the stomach walls. Further, it can be concluded from the results that the total dose rate received both by lungs and stomach, respectively, due to inhalation and ingestion of radon was however, less than the UNSCEAR and WHO recommended limit of $1 \mathrm{mSv} / \mathrm{year}$ for public.

Binesh et al. (2010) in a similar study reported ACED values received by stomach and lungs, respectively, to range from 0.012 to $8.836 \mu \mathrm{Sv} /$ year and $0.160-122.72 \mu \mathrm{Sv} / \mathrm{year}$, while Nikolov et al. (2011) recorded the radiation dose to stomach and lungs, respectively, to range from 0.702 to 3.348 $\mu \mathrm{Sv} /$ year and 9.75 to $46.5 \mu \mathrm{Sv} /$ year from public drink fountains; and 0.135 to $263.34 \mu \mathrm{Sv} /$ year and 1.125 to $3,657.5 \mu \mathrm{Sv} /$ year, respectively, from bottled drinking water and tap water. 
Correlation between radon and geology of the study area

The present study area, being a part of Bangalore Urban district is mainly underlined by $95 \%$ gneisses of Archaean age, and $5 \%$ of younger granites of Proterozoic age geologically. Granites and gneisses of peninsular gneissic group constitute major aquifers in the urban district. The gneisses belong to Peninsular Gneissic Complex (PGC), which is a complex of different types of granitic rocks, acid intrusives, and metamorphic rocks like granitised older crystalline rocks/granodiorites, migmatites, tonalites, etc. It is these formations which are responsible for higher concentration of radon in the groundwater from the study area. Similar observation of high values of radon is reported in sheared gneisses compared to phyllites and schists (Choubey and Ramola 1997), while Godish (2001) opined that radon is produced by the radioactive decay of radium-226, which is found in uranium ores, phosphate rock, shales, igneous and metamorphic rocks such as granite, gneiss, and schist, and, to a lesser degree, in common rocks such as limestone. Ramola et al. (2006) also opines that the radon level was found higher in the area consisting of granite, quartz porphyry, schist, phyllites slates and lowest in the area having sedimentary rocks, predominantly dominated by quartzite rocks. Even Hunse et al. (2010) were of the opinion that high radon concentration zone is not only restricted to the granitic body, but also to the fringe area of the granitic body and suggested that there existed control of granitic body on radon occurrence. Thus, it can inferred that many factors such as geology, abundance and complexation of parent radionuclides (viz., ${ }^{238} \mathrm{U}$ and ${ }^{226} \mathrm{Ra}$ ), geochemical properties of parent radionuclides, porosity of the parent radionuclides bearing materials, and the surrounding rocks and sediment, rock sizes, radionuclide sorption capacity of the surrounding materials (i.e., rocks or soils), and hydrological conditions are the potential parameters that can affect the concentration of ${ }^{222} \mathrm{Rn}$ in groundwater [Paulus 1995; Porcelli and Swarzenski 2003; Wong et al. 1992]. It can be concluded that a strong correlation exists between the lithology of hard rocks and the concentration of radon in groundwater in the study area.

\section{Conclusion}

The present study revealed that the radon concentration in majority of the groundwater samples from the study areas was higher than the EPA's MCL value and WHO/EU's reference level. Further, granites and gneisses of peninsular gneissic group (PGC) constituting major aquifers in the study area are responsible for higher concentration of radon in the groundwater. However, the overall ACED rate resulting from radon emanating from surface and groundwater in the study area was increasing with increase in radon activity, age and ACRs, but were significantly lower than UNSCEAR and WHO recommended limit of $1 \mathrm{mSv} / y e a r$ except for few groundwater samples. Even the ACED rate received by bronchial epithelium due to inhalation of waterborne radon in air was significantly very high over that of stomach walls via ingestion.

It can be concluded that the radiation dose from radon in drinking water is on average low relative to that from the inhalation of radon present in indoor air. The risk due to radon in water (which is typically low) compared with total inhaled radon is still distinct because exposure occurs by both consumption of dissolved gas and inhalation of released radon and its daughter radionuclides from the water, and therefore not neglected. Because, in household, water usages such as showers, baths, dishwashers, laundries, and toilets all provide adequate aeration to release a high percentage of the waterborne radon into household air. Hence, it is better to take measures to reduce exposure to radon in drinking water and hence, mitigation processes of reducing radon gas related exposure in the home or workplace such as increasing indoor ventilation (open windows, air-to-air heat exchangers), removing radon progeny from the air (filters, fans) or ventilating the soil surrounding the building should be encouraged. Since, the process of boiling of water also sets free the radon gas from the water into the air, there should be no apprehensions about a radiation dose from drinking coffee or tea. However, it is important to make sure that boiling takes place in well-ventilated areas to reduce the risks of inhaling radon gas. Further, with a view of making a risk assessment study concerning the exposed population in the study area as accurate as possible and to increase awareness and mitigate possible health hazards among public, constant endeavor and continuous investigation on an expanded network to control the radiation component due to radon and their progenies should be reinforced. Finally, screening of relevant radiological as well as geological parameters in high radon activity concentration area in Bangalore, in particular, and Karnataka state, India in general is also recommended as it may be because of the leakage of high activity underground radon.

Acknowledgments Authors are thankful to the Board of Research in Nuclear Sciences (BRNS), Bhabha Atomic Research Centre (BARC), Government of India, Mumbai.

\section{References}

Ali N, Khan EU, Akhter P, Khan F, Waheed A (2010) Estimation of mean annual effective dose through radon concentration in the water and indoor air of Islamabad and Murree. Radiat Prot Dosimetry 141(2):183-191 
Al-Kazwini AT, Hasan MA (2003) Radon concentration in Jordanian drinking water and hot springs. J Radiol Prot 23:439-448

Arora V, Bajwa BS, Singh S (2011) Measurements of radon concentrations in ground water samples of tectonically active areas of Himachal Pradesh, North West Himalayas, India. Radiat Prot Environ 34:50-54

Barnett JM, Holbert KE, Stewart BD, Hood WK (1995) Lung dose estimates from ${ }^{222} \mathrm{Rn}$ in Arizona groundwater based on Liquid Scintillation measurements. Health Phys 68:699-703

Binesh A, Mohammadi S, Mowlavi AA, Parvaresh P (2010) Evaluation of the radiation dose from radon ingestion and inhalation in drinking water. Int $\mathbf{J}$ Water Resour Environ Eng 2(7):174-178

Boice JD, Mumma M, Schweitzer S, Blot WJ (2003) Cancer mortality in a Texas county with prior uranium mining and milling activities, 1950-2001. J Radiol Prot 23(3):247-262

Bourai AA, Gusain GS, Rautela BS, Joshi V, Prasad G, Ramola RC (2012) Variations in radon concentration in groundwater of Kumaon Himalaya, India. Radiat Prot Dosimetry. doi:10.1093/ $\mathrm{rpd} / \mathrm{ncs} 186$

Cevik U, Damla N, Karahan G, Celebi N, Kobya AI (2006) Natural radioactivity in tap waters of eastern black sea region of Turkey. Radiat Prot Dosimetry 118:88-92

Chandrashekara MS, Veda SM, Paramesh L (2012) Studies on radiation dose due to radioactive elements present in ground water and soil samples around Mysore City, India. Radiat Prot Dosimetry 149(3):315-320. doi:10.1093/rpd/ncr231

Chen Jing (2010) Doses to children from intakes by ingestion. Radiat Prot Dosimetry 142(1):46-50

Choubey VM, Ramola RC (1997) Correlation between geology and radon levels in ground water, soil and indoor air in Bhilangana Valley, Garhwal Himalaya, India. J Environ Geol 32:258-262

Choubey VM, Ramola RC, Sharma KK (1994) Soil Gas and Indoor radon studies in Doon Valley, India. Nucl Geophys 8:49-54

Choubey VM, Ramachandran TV, Negi MS, Ramola RC (2000) Calibration of radon emanometer. Ind J Environ Prot 20:329-331

Duenas C, Fernandez MC, Carretero J, Liger E, Canete S (1999) ${ }^{226} \mathrm{Ra}$ and ${ }^{222} \mathrm{Rn}$ concentrations and doses in bottled waters in Spain. J Environ Radioact 45:283-290

Durridge Company Inc (2009) RAD7 RAD $\mathrm{H}_{2} \mathrm{O}$-radon in water accessory owner's manual. [http://www.durridge.com/document ation/RADH2OManual.pdf]

Enderle GJ, Friedrich K (1995) East-German uranium miners (Wismut)—exposure conditions and health consequences. Stem Cells 13(Suppl. 1):78-89

EU (1998) European Union Commission directive of defining requirements for the parameters for radioactivity for monitoring the quality of water for the Council Directive 98/83 of 3 November 1998 on the quality of water intended for human consumption, Draft v3.0 29/11/2005

EU (2001a) European Union Commission Recommendation of 20 December 2001 on the protection of the public against exposure to radon in drinking water, 2001/982/Euratom (notified under document number C(2001) 4580)(http://eurpa.eu.int/comm/ energy/nuclear/radioprotection/ doc.legislation/019280_en.pdf)

EU (2001b) European Union Commission Recommendation on the protection of the public against exposure to radon in drinking water supplies. Office J Eur Community L 344:85-88

Folger PF, Nyberg P, Wanty RB, Poeter E (1994) Relationship between ${ }^{222} \mathrm{Rn}$ dissolved in groundwater supplies and indoor ${ }^{222} \mathrm{Rn}$ concentrations in some Colorado Front Range houses. Health Phys 67:244-252

Gillmore GK, Grattan J, Pyatt FB, Phillips PS, Pearce G (2002) Radon, water and abandoned metalliferous mines in the UK: Environmental and Human Health implications. In: Merkel BJ,
Planer-Friedrich B, Wolkersdorfer (eds) Ch.: Uranium in the aquatic environment, pp 65-76

Godish T (2001) Indoor environment quality. CRC Press LLC, Boca Raton

Gruber V, Maringer FJ, Landstetter C (2009) Radon and other natural radionuclides in drinking water in Austria; measurement and assessment. Appl Radiat Isot 67:913-917

HO W (2008) World Health Organisation-Guidelines for drinkingwater quality, vol 1. World Health Organisation Publication, New York, pp 197-209

Hunse TM, Najeeb KMd, Rajarajan K, Muthukkannan M (2010) Presence of radon in groundwater in parts of Bangalore. J Geol Soc India 75:704-708

IAEA (1996) International Atomic Energy Agency-international basic safety standards for protection against ionizing radiation and for the safety of radiation sources. Vienna, Safety Series-115

ICRP (1994) International Commission on Radiological ProtectionProtection against ${ }^{222} \mathrm{Rn}$ at home and at work. Pergamon Press, ICRP Publication No. 65, Oxford

ICRP (1996) International Commission on Radiological ProtectionAge-dependent doses to members of the public from intake of radionuclides: part 5 compilation of ingestion and inhalation dose coefficients. ICRP Publication 72. Ann ICRP 26(1)

Kearfott KJ (1989) Preliminary experiences with 222Rn gas Arizona homes. Health Phys 56:169-179

Kendal GM, Smith TJ (2002) Dose to organs and tissues from radon and its decay products. J Radiol Prot 22:389-406

Khan AJ (2000) A study of indoor radon levels in Indian dwellings, influencing factors and lung cancer risks. Radiat Meas 32:87-92

Khan F, Ali N, Khan EU, Khattak NU, Khan K (2010) Radon monitoring in water sources of Balakot and Mansehra cities lying on a geological fault line. Radiat Prot Dosimetry 138(2):174-179

Khattak NU, Khan MA, Shah MT, Javed MW (2011) Radon concentration in drinking water sources of the Main Campus of the University of Peshawar and surrounding areas, Khyber Pakhtunkhwa, Pakistan. J Radioanal Nucl Chem 290:493-505. doi:10.1007/s10967-011-1297-2

Kusyk M, Ciesla KM (2002) Radon levels in household waters in southern Poland. Nukleonika 47:65-68

Lee JM, Kim G (2006) A simple and rapid method for analyzing radon in coastal and ground waters using a radon-in-air monitor. J Environ Radioact 89:219-228

Li X, Zheng B, Wang Y, Wang X (2006) A study of daily and seasonal variations of radon concentrations in underground buildings. J Environ Radioact 87:101-106

Mose DG, Mushrush GW, Chrosniak C (1990) Indoor radon and well water radon in Virginia and Maryland. Arch Environ Contam Toxicol 19(6):952-956

Mowlavi AA, Fornasier MR, de Denaro M, Binesh A (2012) Indoor radon measurement and effective dose assessment of 150 apartments in Mashhad, Iran. Environ Monit Assess 184:10851088. doi:10.1007/s10661-011-2022-X

Muhammad BG, Jaafar MS, Azhar AR, Akpa TC (2012) Measurements of ${ }^{222} \mathrm{Rn}$ activity concentration in domestic water sources in Penang, Northern Peninsular Malaysia. Radiat Prot Dosimetry 149(3):340-346. doi:10.1093/rpd/ncr230

Németh Cs, Tokonami S, Ishikawa T, Takahashi H, Zhuo W, Shimo M (2006) Measurements of radon, thoron and their progeny in Gifu prefecture, Japan. J Radioanal Nuclear Chem 267(1):9-12

Nikolov J, Todorovic N, Forkapic S, Bikit I, Mrdja D (2011) Radon in drinking water in Novi Sad. World Acad Sci Eng Technol 76:307-310

Oner F, Yalim HA, Akkurt A, Orbay M (2009) The measurements of radon concentrations in drinking water and the Yesilirmak River water in the area of Amasya in Turkey. Radiat Prot Dosimetry 133(4):223-226 
Paulus LR (1995) An evaluation of radon concentrations in ground water from wells and springs in the State of Idaho. MS thesis, Idaho State University, Pocatello, Idaho

Porcelli D, Swarzenski PW (2003) The behavior of U- and Th-series nuclides in groundwater. Reviews in Mineralogy and Geochemistry. Geochem Soc Mineral Soc Am 52:317-356

Pourhabib Z, Binesh A, Arabshahi H (2011) Evaluation of Radiation dose from radon ingestion and inhalation in water supplies of Sadatshahr and Javaherdeh in Iran. Environ Res J 5(4):170-172. doi:10.3923/erj.2011.170.172

Prichard HM (1987) The transfer of radon from domestic water to indoor air. J AWWA 79(4):159-161

Ramola RC, Singh S, Virk HS (1988) Radon studies over main Boundary Thrust near Dehradun India. Nucl Tracks Radiat Meas 15:617-619

Ramola RC, Sandhu AS, Singh M, Virk HS (1989) Geochemical exploration of uranium using radon measurement techniques. Nucl Geophy 3:57-69

Ramola RC, Singh M, Sandhu AS, Singh S, Virk HS (1990) The use of radon as an earthquake precursor. Nucl Geophys 4:275-287

Ramola RC, Choubey VM, Prasad Y, Prasad G, Bartarya SK (2006) Variation in radon concentration and terrestrial gamma radiation dose rates in relation to the lithology in southern part of Kumaon Himalaya, India. Radiat Meas 41:714-720

Rusconi R, Forte M, Badalamenti P, Bellinzona S, Gallini R, Maltese S, Romeo C, Sgorbati G (2004) The monitoring of tap waters in Milano: planning, methods and results. Radiat Prot Dosimetry 111(4):373-376. doi:10.1093/rpd/nch057

Savidou A, Sideris G, Zouridakis N (2001) Radon in public water supplies in Migdonia Basin, central Macedonia, northern Greece. Health Phys 80:170-174

Sohrabi M (1998) The state of the art on worldwide studies in some environments with elevated naturally occurring radioactive materials (NORM). Appl Radiat Isot 49:169-188

Somashekar RK, Ravikumar P (2010) Radon concentration in groundwater of Varahi and Markandeya river basins, Karnataka State, India. J Radioanal Nucl Chem 285:343-351. doi: 10.1007/s10967-010-0573-x

Somlai K, Tokonami S, Ishikawa T, Vancsura P, Gáspár M, Jobbágy V, Somlai J, Kovács T (2007) ${ }^{222} \mathrm{Rn}$ concentration of water in the Balaton Highland and in the southern part of Hungary, and the assessment of the resulting dose. Radiat Meas 42:491-495

Stringer C, Burnett WC (2004) Sample bottle design improvements for radon emanation analysis of natural waters. Health Phys $87: 642-646$
Tanner AB (1986) Geological factors that influence radon availability. Indoor radon levels, Publ. SP-54, Air Pollution control Assoc., Pittsburg, PA, pp 1-12

Tayyeb ZA, Kinsara AR, Farid SM (1998) A study on the radon concentrations in water in Jeddah (Saudi Arabia) and the associated health effects. J Environ Radioact 38(1):97-104

UNSCEAR (1993) United Nations Scientific Committee on the effects of atomic radiation-sources and effects of ionizing radiation, 1993 report to the General Assembly, with scientific annexes. United Nation Sales Publication E.94.IX.2. United Nations, New York

UNSCEAR (2000) United Nations Scientific Committee on the Effects of Atomic Radiation-Exposures from natural radiation sources, January 2000 draft report. United Nations, New York

USEPA (1991) United States Environmental Protection AgencyNational primary drinking water regulations for radionuclides: notice of proposed rule-making. Fed Reg 56:33050-33127

Vitz E (1991) Toward a standard method for determining waterborne radon. Health Phys 60:817-829

WHO (World Health Organization) (1993) Guidelines for drinking water quality, vol 1, 2nd edn. WHO Recommendations, Geneva

WHO (2004) World Health Organisation-Guidelines for drinking water quality, 2nd edn. WHO, Geneva

Wong CS, Chin Y, Gschwend PM (1992) Sorption of radon-222 to natural sediments. Geochim Cosmochim Acta 56:3923-3932

Xinwei L (2006) Analysis of radon concentration in drinking water in Baoji (China) and the associated health effects. Radiat Prot Dosimetry 121(4):452-455

Xinwei L, Xiaolan Z (2004) Study of the radon concentrations in drinking water from three main cities of Shaanxi Province, China. Environ Geol 45:1082-1086

Yamada Y, Sun Q, Tokonami S, Akiba S, Zhuo W, Hou C, Zhang S, Ishikawa T, Furukawa M, Fukutsu K, Yonehara H (2006) RadonThoron discriminative measurements in Gansu province, China, and their implication for dose estimates. J Toxicol Environ Health Part A 69:723-734. doi:10.1080/15287390500261265

Yogesh PG, Choubey P, Ramola VC (2009) Geohydrological control on radon availability in groundwater. Radiat Meas 44(1):122-126

Yu KN, Guan ZJ, Stokes MJ, Young ECM (1994) A preliminary study on the radon concentations in water in Hong Kong and the associated health effects. Appl Radiat Isot 45:809-810

Zhuo W, Iida T, Yang X (2001) Occurrence of ${ }^{222} \mathrm{Rn},{ }^{226} \mathrm{Ra},{ }^{228} \mathrm{Ra}$ and $\mathrm{U}$ in groundwater in Fujain province. Chin $\mathrm{J}$ Environ Radioact 53:111-120 